https://doi.org/10.21122/1029-7448-2018-61-6-517-526

UDC 691

\title{
Specific Features of Heat- and Mass Transfer Processes in Road Dressings
}

\author{
B. M. Khroustalev ${ }^{1)}$, Liu Tingguo ${ }^{2}$, V. D. Akeliev ${ }^{1)}$, Yu. H. Aliakseyeu ${ }^{1}$, \\ Shi Jicun' ${ }^{2}$, V. V. Zankovich ${ }^{1)}$ \\ ${ }^{1)}$ Belarusian National Technical University (Minsk, Republic of Belarus), \\ ${ }^{2)}$ Gaoyuan Company (Henan Province, People's Republic of China)
}

\begin{abstract}
The paper presents a fragment of on-going investigations directed on creation of optimum data environment that ensures an access to world scientific journals and other publications which are necessary for qualitative implementation of works on priority directions of R\&D in the field of road-construction industry in the period of 2016-2020. A citation analysis has been applied while using data of Journal Citation Reports for selection of world scientific serial publiccations which are necessary for execution of investigations on heat and mass transfer in road dressings. The road dressings are considered as open heterogeneous thermodynamic systems. Their deformations occur under various climatic conditions due to heat- and mass transfer processes and interaction of transport flows and road surface. Crack formation takes place in depth of the road dressings and on road surfaces as a result of temperature, mass transfer processes. As it is known material structure of constructive layers especially which are created with the help of technogenic wastes (asphalt-concrete, concrete, reinforced concrete scrap and products of its recycling, brick rubble, various wastes of production etc.) influence on heat- and mass transfer. The paper presents results of investigations on heat flows, boundary layers according to air viscosity, velocity of geometric permeability characteristics, capillary pressures in road pavements.
\end{abstract}

Keywords: road dressing, heat- and mass transfer, structure, temperature, stresses, surface, deformation, crack formation, model, velocity, investigations, density, time, boundary layer, flow, longevity

For citation: Khroustalev B. M., Tingguo Liu, Akeliev V. D., Aliakseyeu Yu. H., Jicun Shi, Zankovich V. V. (2018) Specific Features of Heat- and Mass Transfer Processes in Road Dressings. Energetika. Proc. CIS Higher Educ. Inst. and Power Eng. Assoc. 61 (6) 517-526. https://doi.org/10. 21122/1029-7448-2018-61-6-517-526

\section{Особенности тепло- и массообменных процессов в дорожных одеждах}

\author{
Б. М. Хрусталев ${ }^{1)}$, Лю Тингуо ${ }^{2)}$, В. Д. Акельев ${ }^{1)}$, Ю. Г. Алексеев ${ }^{1)}$, \\ Ши Джицунь ${ }^{2)}$, В. В. Занкович ${ }^{1)}$ \\ 1) Белорусский национальный технический университет (Минск, Республика Беларусь), \\ ${ }^{2)}$ Компания «Гаоюань» (провинция Хэнань, Китайская Народная Республика) \\ (C) Белорусский национальный технический университет, 2018 \\ Belarusian National Technical University, 2018
}

Реферат. Работа является фрагментом продолжающихся исследований, направленных на создание оптимальной информационной среды, обеспечивающей доступ к публикациям

Адрес для переписки

Хрусталев Борис Михайлович

Белорусский национальный технический университет просп. Независимости, 150,

220013, г. Минск, Республика Беларусь

Тел.: +375 17 265-96-56

tgv_fes@bntu.by

\author{
Address for correspondence \\ Khroustalev Boris M. \\ Belarusian National Technical University \\ 150 Nezavisimosty Ave., \\ 220013, Minsk, Republic of Belarus \\ Tel.: +375 17 265-96-56 \\ tgv_fes@bntu.by
}


из мировых научных журналов и других изданий, необходимых для качественного выполнения теоретических и экспериментальных исследований по приоритетным направлениям научно-технической деятельности в области дорожно-строительной отрасли в 2016-2020 гг. Использовался цитат-анализ с применением данных Journal Citation Reports отбора мировых научных серийных изданий, необходимых для выполнения исследований по тепло- и массопереносу в дорожных одеждах. Дорожные одежды - открытые гетерогенные термодинамические системы. В различных климатических условиях имеют место их деформации вследствие тепло- и массообменных процессов и взаимодействия транспортных потоков с поверхностью дороги. При наличии температурных, массообменных процессов происходит трещинообразование как по глубине дорожных одежд, так и на дорожных покрытиях. Как известно, на тепло- и массоперенос влияет структура материалов конструктивных слоев, в особенности устроенных из техногенных отходов (асфальтобетонный, бетонный, железобетонный лом и продукты их переработки, кирпичный бой, различные отходы производств и т. д.). Представлены результаты исследований тепловых потоков пограничных слоев в зависимости от вязкости воздуха, скорости, геометрических характеристик, проницаемости, капиллярных давлений в дорожных покрытиях.

Ключевые слова: дорожная одежда, тепло- и массоперенос, структура, температура, напряжение, поверхность, деформация, трещинообразование, модель, скорость, исследование, плотность, время, пограничный слой, поток, долговечность

Для цитирования: Особенности тепло- и массообменных процессов в дорожных одеждах / Б. М. Хрусталев [и др.] // Энергетика. Изв. высш. учеб. заведений и энерг. объединений СНГ. 2018. Т. 61, № 6. С. 517-526. https://doi.org/10.21122/1029-7448-2018-61-6-517-526

\section{Introduction}

Automobile roads under various climatic conditions represent open nonlinear heterogeneous thermodynamic systems because road cracking and deformation can be considered in various geographical regions while using synergetic principles as a result of collective behavior, self-organization of structural elements of road pavement if critical temperatures are reached. As a rule, formations emerged due to the above-mentioned processes are specific dissipative structures adapted to environmental conditions and in this case roadway dressings change their mass, energy due to heat- and mass transfer with air and external sources [1-3].

It is necessary to note that one of the examples pertaining to dissipative structure formation is a road dressing with due account of the Benard effect which is in the layer of viscous liquid at a critical temperature difference between bottom and top surfaces. A convection emerges at a definite temperature difference and this process is accompanied by formation of hexagonal cells created by joint molecule motion and there is a heat transfer velocity step due to temperature difference between surfaces and it results in formation of a new structure. At critical temperature difference convection heat transfer velocity is increasing. While having a long temperature decrease the road dressing is scattering a part of accumulated heat to sky dome and various objects and it causes changes in temperature stresses prior to reaching tensile strength. In the case when we have a balance in stress of ultimate strength in road dressing material temperature cracks are liable to emerge and then a step-like withdrawal of pavement heat occurs. For example: decrease of air temperature by $10{ }^{\circ} \mathrm{C}$ leads to changes in temperature field at the road depth up to $0.45-0.50 \mathrm{~m}$. 
Analytical and experimental investigations represent fragments of continuing research activity directed on methodological, experimental pavement developments that ensure minimization in cracking formation in depth and pavement area.

Taking into account some research challenges pertaining to heat- and mass transfer processes that occur during a road construction a development of technology for production of multi-component road pavement on the basis of agglomerates (secondary resources, for example, recycling of existing road dressings) is considered as rather a relevant and priority target. While regenerating single- and multiple-used materials it is necessary to make an analysis of their properties on the basis of heat- and mass transfer processes and it can be done by regulation of their required physical and technical and chemical parameters for actual mixtures, their components. In this regard it is possible to forecast longevity, reliability, thermal and physical characteristics of the road dressing energy efficiency because they depend on correctness of physical and mathematical model, a target function while designing and operating the objects.

\section{Impact of temperature on crack formation in road pavements}

Investigations in Canadian provinces Alberta, Manitoba and Kazakhstan (non-stop high-speed Astana-Shchutchinsk highway) have revealed that changes in temperature up to a critical value initiate first temperature cracks on the surface of road pavement and their number is increasing proportionally to the logarithm of number of the mentioned temperature changes and velocity of temperature cracking is inversely proportional to the number of critical temperature changes. Their propagation is non-uniform in road length; for example, D. R. Hiltunen and R. Roque have shown that there are areas of potential cracks in the top asphalt-concrete layer and cracking can propagate due to temperature stress and with a velocity which is conditioned by spatial non-uniformity of a material.

There is another scheme of low-temperature cracking that uses a mechanical model with averaged pavement characteristics and this model makes it possible to calculate development of a vertical crack. The probability model permits to estimate a total number of temperature cracks on the surface with due account of current averaged value of crack depth and its presupposed propagation along layer thickness. The model considers a number of cooling cycles and it is based on the Paris' law and in accordance with the law linear viscoelastic material properties and crack number depend on regression coefficients which are determined subsequent to the results of field calibration of models, probability of accepted correctness conditions, a crack depth, a road pavement thickness

$$
N=\chi f(\lg h\rangle \lg \delta),
$$

where $N$ - number of cracks; $\chi$ - regression coefficient determined in accordance with the results of model field calibration; $f$ - probability of the fact that the condition (1) is correct; $h$ - crack depth, $\mathrm{m} ; \delta$ - road pavement thickness, $\mathrm{m}$.

Crack formation in various climatic regions is determined by stationary, nonstationary temperature fields which have been calculated with the help of the 
following computer programs: "KASKAD" (CASCADE) set No.011, date of inclusion in Register Book of supporting computer programs - 01.11.2017; "GRADIENT" set No.012, date of inclusion in Register Book of supporting computer programs - 12.03.2018.

Temperature fields for single-layer and multi-layer roads are significant while analyzing heat- and mass transfer processes in road dressings. The paper contains calculations for temperature fields under boundary conditions of the $3^{\text {rd }}$ class while using an analytical method, a net-point method. Multi-layer dressing is considered as a single-layer one while using equivalent thickness for multi-layer objects [4-6].

Temperature in the points of an auxiliary straight line which is located at distance of $\Delta x / 2$ in the moment of time $k$ is calculated in accordance with the expression

$$
t(n+1, k)=\frac{\left(1-\frac{\Delta x}{2} \frac{\alpha}{\lambda}\right) t(n, k)+\Delta x \frac{\alpha}{\lambda} t_{\infty}}{1+\frac{\Delta x}{2} \frac{\alpha}{\lambda}} .
$$

Temperatures $t(0, \tau)$ on concrete pavement surface

$$
t(0, \tau)=\frac{\left(1-\frac{\Delta x}{2} \frac{\alpha}{\lambda}\right) t(1, k)+\Delta x \frac{\alpha}{\lambda} t_{\infty}}{1+\frac{\Delta x}{2} \frac{\alpha}{\lambda}},
$$

where $\Delta x$ - grid pitch (inter-lattice-point distance), $\mathrm{m} ; \lambda$ - equivalent coefficient of road pavement heat conductivity, $\mathrm{W} /(\mathrm{m} \cdot \mathrm{K}) ; \alpha$ - coefficient of heat transfer at pavement surface, $\mathrm{W} /(\mathrm{m} \cdot \mathrm{K}) ; t_{\infty}$ - temperature of boundary layer at road surface, ${ }^{\circ} \mathrm{C}$.

Temperature fields have been calculated in accordance with the following thermal and physical characteristics of the pavement (tab. 1).

Table 1

Thermal and physical characteristics of pavement layers

\begin{tabular}{|l|c|c|c|c|}
\hline \multicolumn{1}{|c|}{$\begin{array}{c}\text { Name } \\
\text { of road dressing layer }\end{array}$} & $\begin{array}{c}\text { Density } \rho, \\
\mathrm{kg} / \mathrm{m}^{3}\end{array}$ & $\begin{array}{c}\text { Heat conducti- } \\
\text { vity coefficient } \lambda, \\
\mathrm{W} /(\mathrm{m} \cdot \mathrm{K})\end{array}$ & $\begin{array}{c}\text { Mass heat capacity } \\
\text { at constant pressure } \\
C_{p}, \mathrm{~kJ} /(\mathrm{kg} \cdot \mathrm{K})\end{array}$ & $\begin{array}{c}\text { Coefficient } \\
\text { of temperature } \\
\text { conductivity } \\
\mathrm{a} \cdot 10^{6}, \mathrm{~m}^{2} / \mathrm{s}\end{array}$ \\
\hline Cement concrete pavement & 2400 & $1.51-1.86$ & 0.84 & 0.84 \\
\hline Asphalt-concrete & 2100 & 1.05 & 1.08 & 0.46 \\
\hline Sand concrete & $1800-2500$ & 0.70 & 710 & 0.46 \\
\hline $\begin{array}{l}\text { Gravel aggregate concrete } \\
\text { or crushed natural stone } \\
\text { concrete }\end{array}$ & 2400 & 1.51 & 840 & 0.75 \\
\hline Slag concrete & $1120-1500$ & $0.60-0.70$ & 800 & 0.63 \\
\hline Cement-sand mortar & $1800-2000$ & $0.60-1.20$ & 840 & 0.56 \\
\hline Flyash concrete & $1000-1800$ & $0.29-0.7$ & 840 & 0.43 \\
\hline $\begin{array}{l}\text { Sand for construction } \\
\text { works (GOST 8736-77) }\end{array}$ & 1600 & 0.35 & 840 & 0.26 \\
\hline
\end{tabular}


Temperature fields at these boundary conditions have been calculated according to Biot (Bi) and Fourier Fo numbers from nomograms

$$
\mathrm{Bi}=\frac{\alpha x}{\lambda} \mathrm{Fo}=\frac{\alpha \tau}{x^{2}}
$$

Calculations have shown that temperatures at pavement surface up to $15{ }^{\circ} \mathrm{C}$ with air temperature changes lead to changes of pavement temperature fields in depth up to $0.02 \mathrm{~m}$ by $7-8{ }^{\circ} \mathrm{C}$.

\section{Impact of technogenic wastes \\ on heat- and mass transfer in road dressings}

Construction and road objects exert a significant impact on environmental situation, social and economic problems for any country. So it is necessary to have theoretical investigations, justification of the taken decisions for construction of road dressings including roadway platform and groundwork base which is due to solution of resource-saving matters, prevention of environmental pollution. Priority goals are ecological and material science that allow to ensure selection of technogenic wastes of construction process for production of more ecologically friendly, safe construction materials. It is necessary to consider the possible use of asphalt-concrete, concrete, reinforced concrete, brick, wooden rubble, plastering, various backfilling wastes not as building refuse creating problems but they must be accepted as easily used materials for repair and restoration construction works, these materials can be recycled, mechanically separated in fractions using various methods. The investigations demonstrate that while applying materials obtained with the help of the above-mentioned methods it is possible to make concrete with strength up to $70 \%$ from brand nominal value. In order to meet a number of longevity requirements it is expediently to use standard materials and state-of-the-art technologies along with substandard materials and by-products of metallurgical production that allow to lower technicaland-economic indices while constructing automobile roads by $1.2-1.5$-fold, and also fine sand with fineness modulus $0.6-0.8$, finely powdered fractions of granulated slag with specific surface not less than $300 \mathrm{~m}^{2} / \mathrm{kg}$ and others.

\section{Heat and mass physical characteristics}

An actual problem for various climatic regions is optimization, analysis, presentation of analytical, numerical, experimental methodologies for evaluation of heat and mass conductivity ratio, heat absorption of compositions (broken stone, concrete, fill material, cement synthesized solutions, their structures).

Analytical and experimental, engineering calculations of thermal resistance for conventional automobile road pavements give ground to consider them as semi-bounded bodies at cyclic fluctuation of free-air temperature, transitions from positive to negative values, with various heat transfer coefficients. 
It is also necessary to take into account radiation heat transfer between sky dome, surfaces of construction roadside objects, afforestation, transport facilities and so on.

Densities of heat flows in the materials of road pavements depend on geometrical dimensions of road-bed (width), radiation characteristics (spectral, total emissivity), local average values of surface temperature and so on. Deformation characteristics, longevity, crack resistance of road, airdrome pavements are determined by indices of air temperature fluctuations, their attenuation in the roadbed, because an index of heat inertia depends on the products of heat conductivity thermal resistances and their coefficients of heat absorption. "A layer of violent temperature fluctuations" which is located at a specific distance from the road-bed surface plays a significant role for longevity of road dressings.

There are temperature fluctuations in the road, concrete and asphalt-concrete pavements and due to this reason stresses, deformations cause temperature cracks. Temperature deformations include free stressed deformations which are proportional to temperature gradients and which are stipulated by temperature stresses characterized by linear temperature expansion coefficients. The following physical and mechanical properties are changing in the course of time: strength, modules of elastic longitudinal deformations, shift, longitudinal deformation coefficients for all components. In such a case creeping leads to decrease in stresses initiated by forced deformations (temperature deformation, shrinking deformation, re-distribution of stresses). So temperature of road pavement materials depends on coordinates, time, heat and physical characteristics of a material.

While using variation algebraic, integral substitutions, stepwise approximations, integral transformations of numerical and other methods an analysis of thermo-technical calculations, mass transfer has shown that majority of road pavements have limited heat and mass resistance at relatively small external actions and radiation characteristics of surfaces.

Temperature fluctuations of the road dressings are of great importance and they are conditional on temperatures which are changing in accordance with seasonal, daily, time intervals. Thus the road dressings have a complicated nonstationary heat regime when temperature fields of the pavements, their gradients of temperatures, mass potentials depend on boundary conditions of 1-4 types. While having boundary condition of $3^{\text {rd }}$ type total (dynamic and heat) heatexchange coefficient in boundary layers is considered as the most important characteristic for heat and mass transfer.

\section{Boundary air layers at road pavements}

Calculations of thickness for dynamic, heat boundary layers at various geometric dimensions of surface, roads, velocity, air temperature have been carried out in respect to various climatic conditions. Some results of these calculations are presented in fig. $1-4$. 


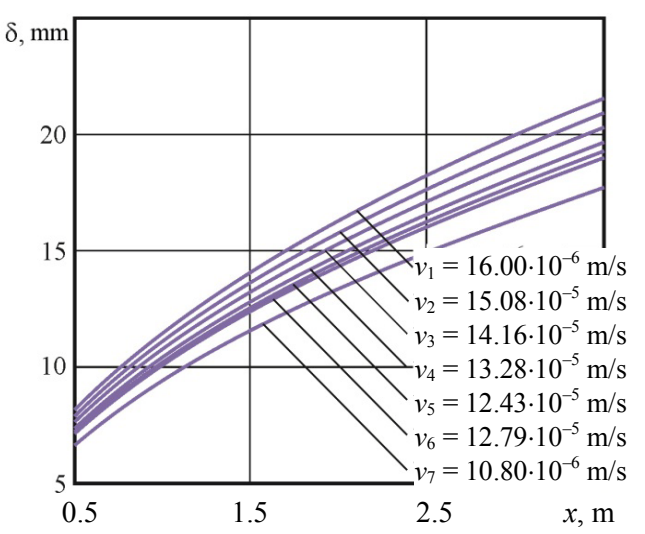

Fig. 1. Dependence of boundary layer thickness $\delta$ on $v=f\left(t_{\infty}\right), \mathrm{m}^{2} / \mathrm{s}($ at $\omega=4 \mathrm{~m} / \mathrm{s})$, road pavement width $(x)$

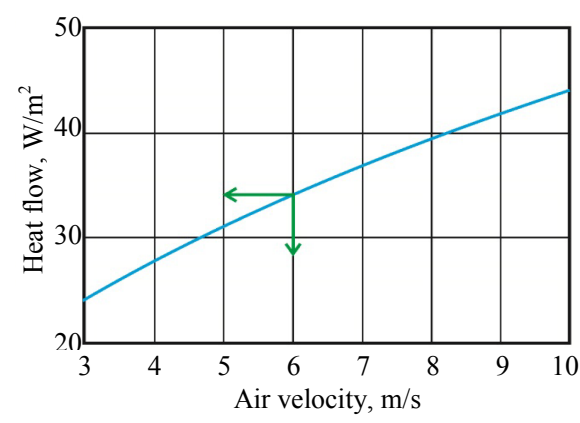

Fig. 3. Dependence of heat flow at road pavement on air motion velocity

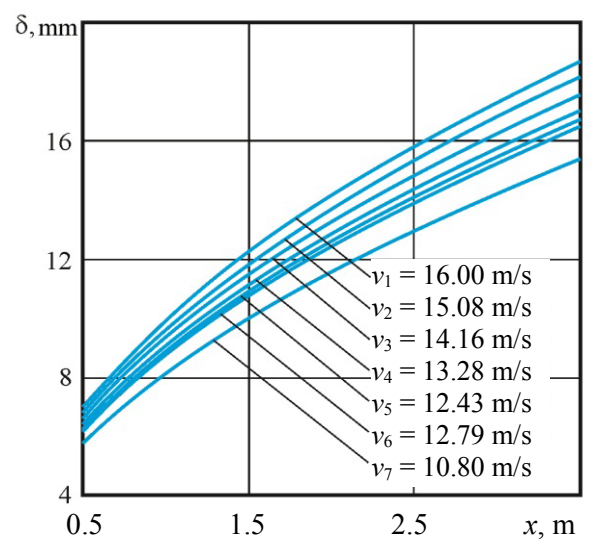

Fig. 2. Dependence of boundary layer thickness $\delta$ on $\omega, \mathrm{m} / \mathrm{s}$, road pavement width $(x)$

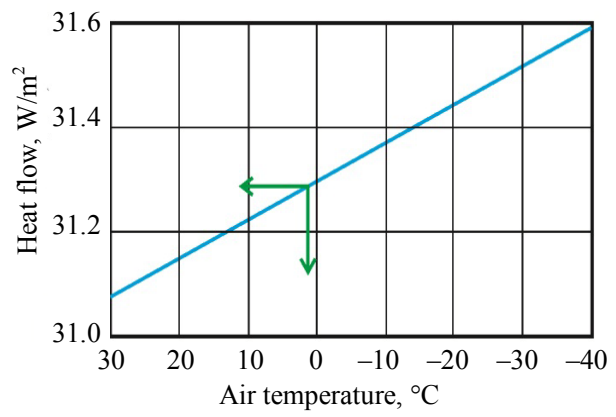

Fig. 4. Dependence of heat flow at road pavement on air temperature

\section{Methodologies for experimental investigations of road pavements}

An analysis of structural characteristics for road pavements have been made with the help of systems including sources of high-speed electrons, X-ray spectrometers, single channel electronic impulse analyzers, an electronic scanning microscope and an optical microscope. Vacuum in optical systems and X-ray spectrometers has been created by an automatic system. An incandescent tungsten filament has served as a source of electrons and converging, stigmatophore, objective lenses ensuring qualitative presentation of the surface have been used as an electronic and optical system.

Stereo images of concrete pavement surfaces (fig. 5) show that dark areas correspond to elements with less atomic weight and lighter areas correspond to elements that have higher atomic weight.

Densities of diffusion, filtration flows at various climatic characteristics, densities of droplet moisture flows serve as a quantitative estimation of capillary processes in the road concrete pavements $[7,8]$.

A device (fig. 6) has been developed and patented for measuring capillary pressure. Methodologies for testing layers of road concrete or asphalt concrete 
pavements for gas- and air-permeability has also been developed and these methodologies characterize material structure and physical and technical characteristics of separate components and pavement as a whole (fig. 7) [9].

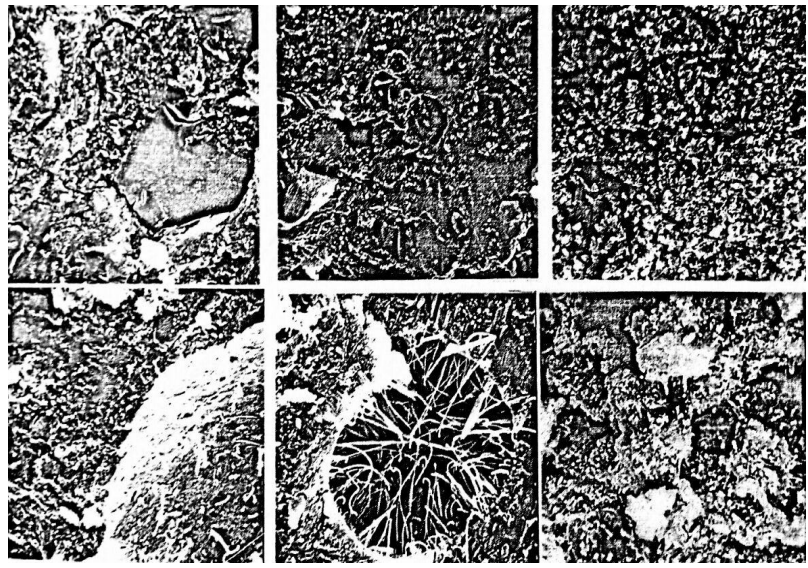

Fig. 5. Stereo images of fracture on concrete material surface $(\times 500$ magnification $)$

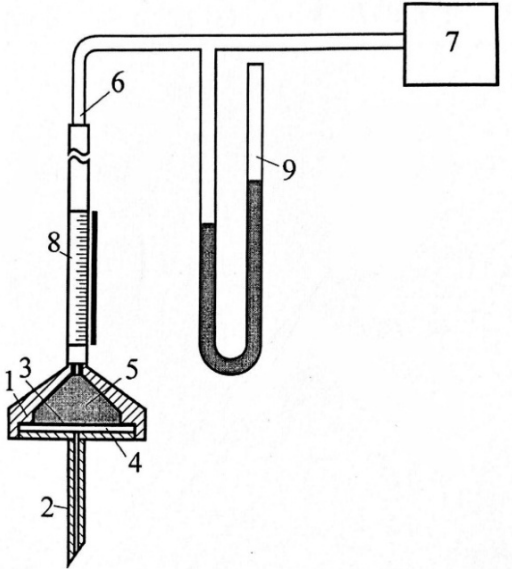

Fig. 6. Scheme of device for measuring capillary pressure: 1 - pressure-sensitive receiver; 2 - capillary needle; 3 - elastic diaphragm; 4, 5 - chambers; 6 - pipeline; 7 - pressure regulation unit; 8 - level meter; 9 - manometer

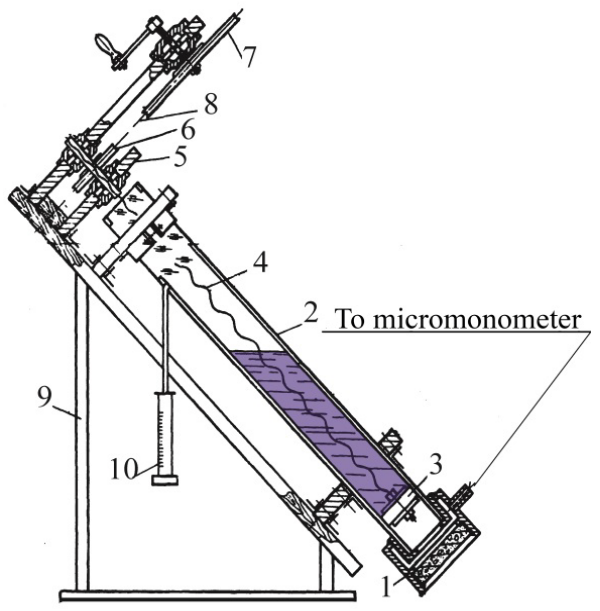

Fig. 7. Scheme of device for determination of air permeability in hard-grained materials: 1 - cassette; 2 - glass tube; 3 - piston; 4 - screw; 5 -nut; 6,7 - sheaves; 8 - belt; 9 - holder; 10 - measuring vessel

Quality of permeability measurements has been reached due to application a special device which was designed in the form of an inclined tube with a rubber hollow piston connected with a mechanism that ensures its translational motion with minimum friction (presence of glycerine solution). An air permeability coefficient is calculated according to volume of air passing through a tube crosssection within specific time interval and pressure difference and such approach has ensured validity of investigations results $[10,11]$. 
Final characteristics of longevity, heat-, physical and technical parameters of road pavements for every variant of road dressing depend on adequacy of a mathematical model, target function while making design.

\section{Full-scale investigations of heat- and mass transfer in road dressings}

The larger the designed project the more probability that solutions will be taken on the basis of such principles as an intuition, a discretionary decision, an experience, common sense. Every variant of selection has its advantages, disadvantages so the most optimum alternative presupposes development, application of scientific method that permits to find solutions which make it possible to assess consequences, to exclude unacceptable variants, to recommend the most efficient proposals. A system approach which takes into account the complicated data of various physical nature is considered as the most appropriate one.

While using a system analysis it is possible to develop a mathematical model of heat and mass transfer in the road dressing and the model is to be developed on the basis of heat-power interaction that includes accounting of partial and general temperature, velocity, pressure, radiation flows, heat and mass accumulating characteristics of materials for constructive layers of road dressings; heat and energy balance of a road object, heat and mass transfer characteristics while being in operation in various periods of time.

Complex investigations have been carried out in various climatic conditions while using multi-functional devices "Testo 435 " and a set of resistance temperature devices КТСП-Н. Convective, radiation flows have been determined with the help of noncontact infrared radiation pyrometers AR852B. Thermo-visors SATHOTFIND (Series L), Company NEC “Ttacer TN 7700" have been used for obtaining thermo-visional measurements of temperature fields on road surfaces in case of solar radiation absence and presence. (The investigations have been made in the Republic of Belarus while constructing Minsk Automobile Ring Road which fully meets all International standards).

\section{CONCLUSIONS}

1. At theoretical justification of a method of crack-resistance calculation at capillary shrinkage of early age concrete with use of approaches of fracture mechanics by the generalized criterion the main assumptions are formulated.

2. The developed model is the hierarchical system, suitable for the description of processes of destruction (destruction) of early age concrete at any levels of consideration of its structure. Having entered the corresponding characteristics for materials of filler and cement and sand solution, it is possible to receive deformative, strength characteristics, parameters of the concrete cracks in case of change of its humidity and temperature (at shrinkage).

3. Being based on the considered regularities of concrete destruction process, it is offered to divide all defects of structure, both initial, and developed as a result of power and not power influences, into 5 main types. The amount of pores and cracks of the first four types depends on concrete porosity, and type $\mathrm{V}$ - and 
on the volume content of grains of small or coarse aggregate. To each type of damages, there corresponds the stress intensity factor, extent of influence and which value on the general crack resistance of material depend on quantity of this type of pores and cracks in concrete volume.

4. The new evidence-based algorithm of crack-resistance calculation at shrinkage of early age concrete by the generalized criterion, which contains the sequence of operations of calculation as for selection of structure, taking into account the factors, influencing capillary pressure and according to characteristics of properties of concrete components, its technological parameters, and for definition of concrete residual resource on its structure and properties and also on the samples, which are selected from structures at early age is offered.

\section{REFERENCES}

1. Lalla J. R. F., Mwasha A. (2014) Investigating the Compressive Strengths of Guanapo Recycled Aggregate Concrete as Compared to that of its Waste Material. West Ind. J. of Engineering, 36 (2), 12-19.

2. Cheng-Chih Fan, Ran Huang, Howard Hwang, Sao-Jeng Chao (2015) The Effects of Different Fine Recycled Concrete Aggregates on the Properties of Mortar. Materials, 8 (5), 2658-2672. https://doi.org/10.3390/ma8052658.

3. Khroustalev B. M., Nesenchuk A. P., Timoshpolsky V. I., Akeliev V. D., Sednin V. A., Kopko V. M., Nerezko A. V. (2007) Heat- and Mass Transfer. Part 1. Minsk, Belarusian National Technical University. 606 (in Russian).

4. Pshembaev M. K., Kovalev Ya. N., Akeliev V. D. (2015) Estimation of the Concrete Pavement Temperature Fields and their Gradients. Energetika. Izvestiya Vysshikh Uchebnykh Zavedenii i Energeticheskikh Ob'edenenii $S N G=$ Energetika. Proceedings of the CIS Higher Educational Institutions and Power Engineering Associations, (4), 54-63 (in Russian).

5. Teltaev B. B. (2015) Regular Features in Self-Organization of Low-Temperature Cracking in Asphalt-Concrete Road Pavement. Doklady Natsional'noi Akademii Nauk Respubliki Kazakhstan = Reports of National Academy of Sciences of the Republic of Kazakhstan, (4), 40-65 (in Russian).

6. Amarasiri A., Grenfell J. (2015) Numerical Modelling of Thermal Cracking of Pavements. International Journal of Pavement Research and Technology, 8 (2), 85-93.

7. Soldatkin M. T., Akel'ev V. D., Astapova L .V. (1973) Device for Testing Construction Material on Air Permeability. Patent USSR No 393682 (in Russian).

8. Baranov S. P., Soldatkin M. T., Akel'ev V. D., Ufimtseva T. A. (1976) Device for Measuring Intra-Capillary Pressure in Porous Bodies. Patent USSR No 516921 (in Russian).

9. Smol'skii R. I., Akel'ev V. D., Batrachenko V. S. (1980) Unit for Testing Construction Materials on Water Permeability. Patent USSR No 763712 (in Russian).

10. Akel'ev V. D., Gurova G. E. (1981) Device for Determination of Air Permeability in Enclosing Structures. Patent USSR No 845098 (in Russian).

11. Soldatkin M. T., Stakhovskaya L. E., Akel'ev V. D. (1982) Device for Measuring Partial Pressure of Water Vapor. Patent USSR No 922554 (in Russian).

Received: 6 August 2018 Accepted: 9 October 2018 Published online: 28 November 2018 